ÖZLEM DOSTBİL $(*)$ - SELMA ÜLGENTÜRK $(* *)$

\title{
BIO-ECOLOGY OF CEDAR SCALE INSECT TOROSASPIS CEDRICOLA (BALACHOWSKY \& ALKAN) (HEMIPTERA DIASPIDIDAE) IN ANKARA, TURKEY ( $\left.{ }^{1}\right)$
}

\author{
(*) Ministry of Forestry and Water Affairs, General Directorate of Forestry, Central Anatolia Forestry Research Institute, \\ Ankara, Turkey \\ (**) Ankara University Faculty of Agriculture, Department of Plant Protection, 06110 Dışkapı, Ankara, Turkey; e-mail: \\ ulgentur@agri.ankara.edu.tr
}

\begin{abstract}
Dostbil Ö., Ülgentürk S. - Bio-ecology of cedar scale insect Torosaspis cedricola (Balachowsky \& Alkan) (Hemiptera Diaspididae) in Ankara, Turkey.

Lebanon cedar, Cedrus libani A. Rich. (Pinaceae) is a significant tree from the historical, cultural, aesthetic, scientific and economic perspectives. It is presently found primarily in the Taurus Mountains with extensive and magnificent forests. Also, it has been frequently used as ornamental tree in urban areas in Turkey and abroad. Cedar scale, Torosaspis cedricola, (Balachowsky \& Alkan) (Hemiptera: Diaspididae) is one of the important pests of cedar trees particularly in urban ecosystem. The bio-ecology of T. cedricola on C. libani is examined four localities during the years 2008 and 2009 in Ankara. T. cedricola has two generations in a year and overwinters as mated females. The sex ratio of T. cedricola is changed 1.8:1-4.8:1 $\left(P: 0^{\top}\right)$ all study areas in both generation and the sex ratio is strongly biased towards female that occur on cedar needles only. The first generation crawlers emerged in late May but the second brood $\mathrm{L}_{1}$ in late July. Adalia bipunctata (L.), Chilocorus bipustulatus (L.), Exochomus quadripustulatus (L.), Harmonia quadripunctata (Pont) (Coleoptera: Coccinellidae) and Cybocephalus fodori minor (Endrödy) (Coleoptera: Cybocephalidae) were determined as predator of the scale, while Diaspiniphagus moeris (Walker) (Hymenoptera: Aphelinidae) was only parasitioid species as natural enemy of T. cedricola. Natural enemies had a negligible effect on populations of T. cedricola in Ankara.
\end{abstract}

Key Words: Cedrus libani, Diaspiniphagus moeris, sex-ratio, damage, Taurus cedar, population dynamics.

\section{INTRODUCTION}

Cedrus libani A.Rich. (Pinaceae) is an evergreen woody plant that typically grows between 500 and $2400 \mathrm{~m}$ altitudes (EvCIMEN 1963; SENITZA, 1989). It occurs naturally in the Taurus Mountains of Southern Turkey, in Western Syria and the Lebanon Mountains. Century-long overexploitation has resulted in devastation or degradation of most forests, but small populations of the species survived in a well-preserved state in isolated areas (BOYDAK \& ÇALIKOĞLU, 2008; MESSINGER et al., 2015). This kind of distribution and site conditions induce morphological, phenotypical and molecular differences among populations (BILGEN et al., 2012). In the recent literature, C. libani is in most cases divided into subsp. libani in Western Syria and the Lebanon mountain ranges and subsp. stenocoma in Southern Turkey (QIAO et al., 2007; DAGHER-KHARRAT et al., 2007; MEssinger et al., 2015), the latter is also known in Turkey as Taurus cedar or Turkish cedar. The range of cedar forest presently covers about 600,000 ha in Turkey (BILGEN et al., 2012). Because of its adaptability, high survival rate and unique wood properties, extended reforestation attempt with C. libani have been made outside its natural distribution for commercial purposes both in Turkey and other countries (BOYdAK, 2003; MESSENGER et al., 2015). C. libani has been used frequently as ornamental trees in parks, gardens, recreations areas and city forest in Turkey. In addition to

\footnotetext{
${ }^{1}$ Original scientific contribution presented and discussed at XIV International Symposium on Scale Insect Studies, Catania-Italy, 13-16 June 2016.
}

anthropogenic and climatic impacts, insect pests can have dramatic effects on tree growth and wood production of Turkish cedar especially in case of pest introduction in a novel area. Scale insects are an important group of pest insects on cedar trees. Ceroplastes floridensis Comstock, Coccus hesperidum Linnaeus (Coccidae), Aspidiotus nerii (Bouché), Chionaspis kabyliensis Balachowsky, Dynaspidiotus abieticola (Koroneos), Dynaspidiotus britannicus (Newstead), D. jaapi (Leonardi), Gomezmenoraspis nr. pinicola (Leonardi), Lepidosaphes juniperi Lindinger, Leucaspis pini (Harting), Torosaspis cedricola (Balachowsky \& Alkan) (Diaspididae), Marchalina hellenica Gennaidus (Marchalinidae) and Phenacoccus arambourgi (Balachowsky) (Pseudococcidae) were recorded as pests in Turkey (BALACHOWSKY \& AlKan, 1956; Selmi, 1979; ÜlgENTÜRK et al., 2012; ÜLGENTÜRK et al.,. 2013; KAYDAN et al., 2014). D. britannicus was as an important pest on cedar. It overwinters as second nymph stage and is bivoltine on $C$. libani in Ankara (AYHAN \& ÜLGENTÜRK, 2011). Although $T$. cedricola a major pest in urban cedars, it does not cause serious damage in cedar forests in Turkey (ŞAHIN \& ÜlgentüRK, 2011). It was described by BALACHOWSKY \& AlKan, (1956) as Acanthomytilus genus (Borchsenius, 1950), but due to on the basis of morphological differences between Acanthomytilus species feeding on woody plants and those feeding on Poaceae, with $A$. farsianus Balachowsky \& Kaussari transferred to the Torosaspis Ülgentürk (ÜLGENTÜRK \& KoZÁR, 2011). T. cedricola caused important precocious needle fall and dieback of C. libani, $C$. atlantica var. glauca, $C$. deodora where used as ornamentals and in natural cedar forests over most of Turkey (ÇANAKÇIOĞLU, 1977; ÜLGENTÜRK, \& TOROS, 1996; ŞAHIN \& 
ÜLGENTÜRK, 2011) and on Cupressus sempervirens in Iran (MoghaddAM, 2004). There is very limited information about the biology of $T$. cedricola. To better manage populations of $T$. cedricola, a better understanding of its biology and ecology is needed. The purpose of this study was to determine the biology, population dynamics and effect of natural enemies on $T$. cedricola under natural conditions in Ankara, Turkey.

\section{MATERIALS AND METHODS}

Field studies were conducted in four localities in Ankara provinces during the years 2008 and 2009 (Fig. I). Samples were collected once a month between November-April and one a week between April-October from each cedar tree (from 4 sides), 144 needles ( 4 X 3 cluster X 4 needles) totalling 576 needles from 4 localities. The number of eggs, $1^{\text {st }}$ - and $2^{\text {nd }}-$ instar nymphs, pupae, empty tests and adult females (young and with eggs) were counted on each needle sample. The time of appearance of each stage, its duration, the sex ratio, changes in populations and overwintering stage were determined under natural conditions. For confirmation of particular instars, individuals were transferred to $70 \%$ alcohol and slide mounted as described by KOSZTARAB \& KozÁR (1988). Determination of effects of natural enemies on cedar scale, every stage was examined under a stereo microscope and counted as live, dead, parasitized or chewed upon by predators. Climatic data are supplied by Turkish State Meteorological Service. MINITAB 15 and Kruskal-Wallis test were used for statistical analyses.

\section{RESULTS AND DISCUSSION}

The life circles of $T$. cedricola were very similar all four localities in Ankara. Therefore mainly the results of bio- ecology of cedar scale at the campus of Agriculture Faculty site are presented below. T. cedricola is fed only on the needles of cedar. The overwintered adult females began feeding in early May and deposited their first eggs near the end of May (29.v.2008). T. cedricola is ovoviviparous and deposits its eggs under the scale test. The eggs are oval in shape and cream in colour (Fig. II, 3 and 7). Oviposition continues until the end of June (26.vi.2008) (Fig IV, VI). Both eggs and first instar nymphs are often seen together under the same adult female's scale (Fig. II, 7), indicating that eggs hatch in a very short time. Average number of eggs ranged between 2,61-4,96/ $q$ under the test (Table 1). Eggs within female's body numbered 8-15 eggs (Fig. II 1,2). During oviposition time temperature was $15,52(11,3-22,7)$ $\mathrm{C}^{\circ}$ in Ankara (Fig. V). Oviposition required nearly four weeks in the spring season (Fig. VI). First instar nymphs remained on needles until late June (26.vi.2008). The maximum number of crawlers reached (150 nymphs/ on needles) at the beginning of June (5.vi.2008) (Fig. IV). They settled on young needles of the current year. Second stage nymphs were determined by the first week of June (5.vi2008) (Fig. II 5 and 8) and remained until the end of June (26.vi.2008). Pupae, adult males and adult females were found during nearly three weeks of July (227.vii.2008). Adult female numbers peaked at 432 scale/144 needle by the second week of July (16.vii.2008) (Fig. IV). The temperature during this period of time averaged 24,9 $(21,4-30,3) \mathrm{C}^{\circ}$ in Ankara (Fig. V). The scale of the female is oyster-shell shaped, light to dark brown in colour, with the exuviae situated at the narrower end. The living adult female of $T$. cedricola is elongate in shape, derm membranous, cream in color, pygidium yellowish (Fig. II, 7). Eggs and crawlers of the second generation were detected at the end of July (23.vii.2008). The summer generation of T. cedricola completes oviposition in two weeks. First instar nymphs remained until the end of July (23.vii.2008). The second instar nymphs were seen between last week of July and third

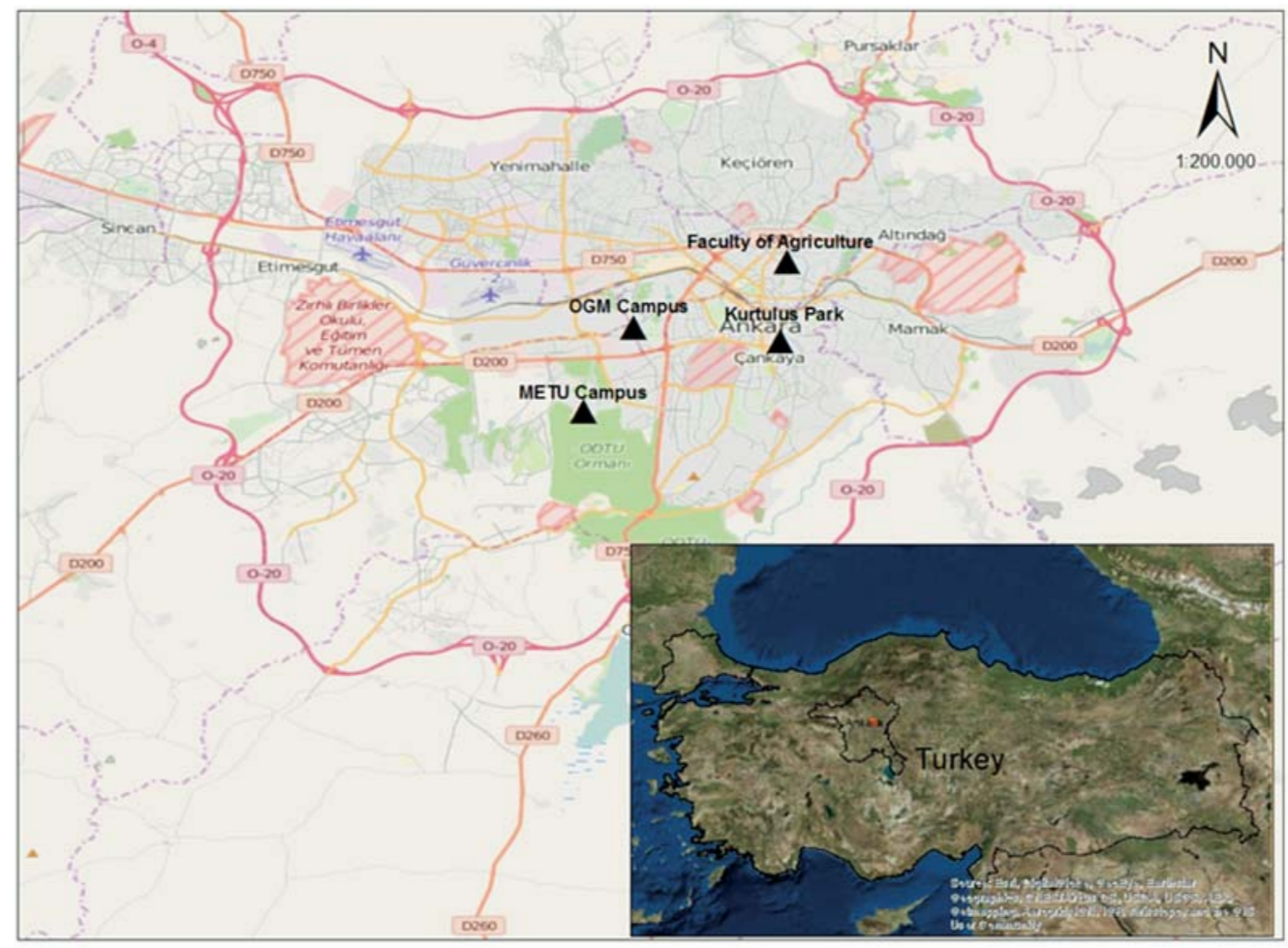

Fig. I - Study areas in Ankara. 

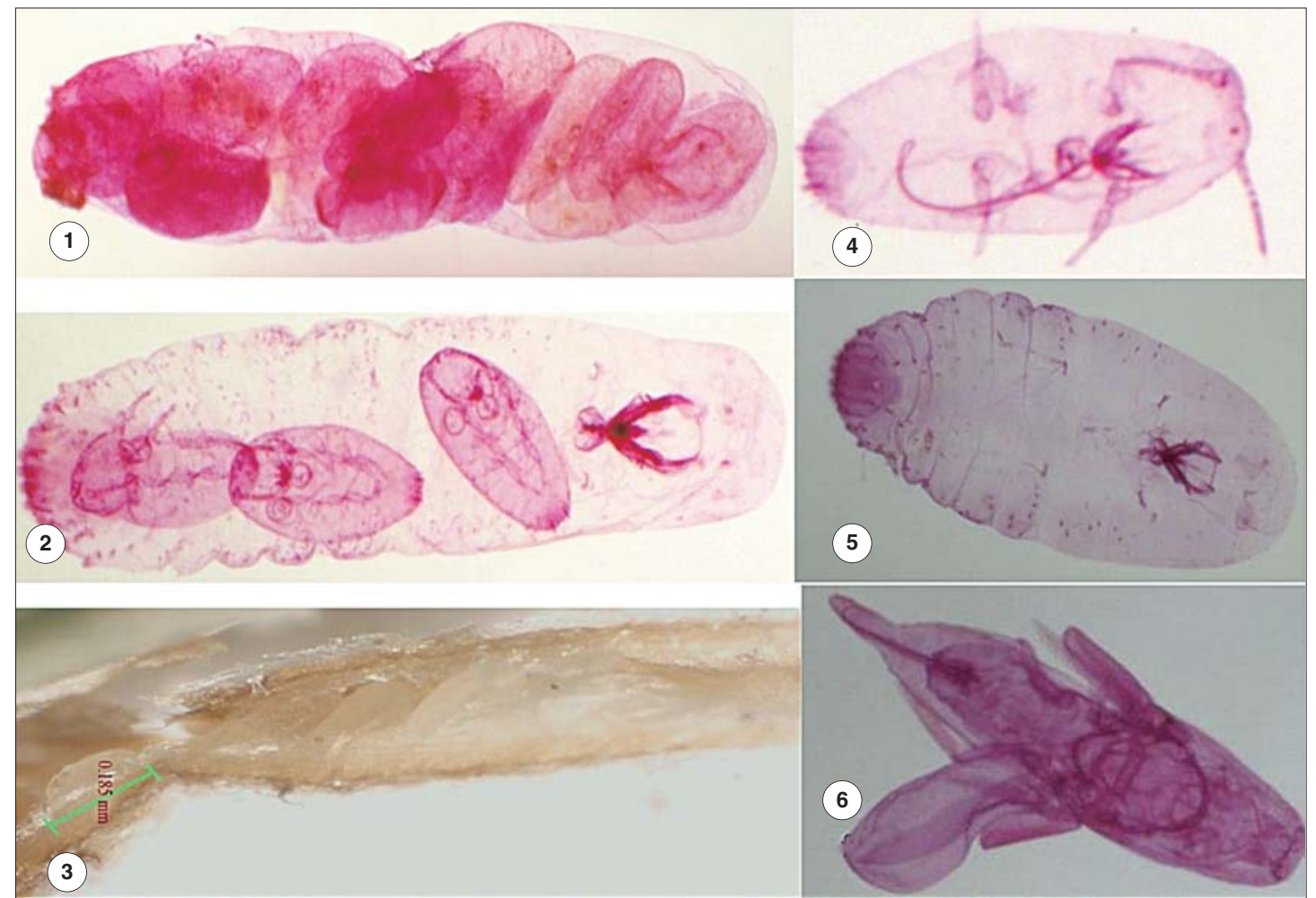

(5)
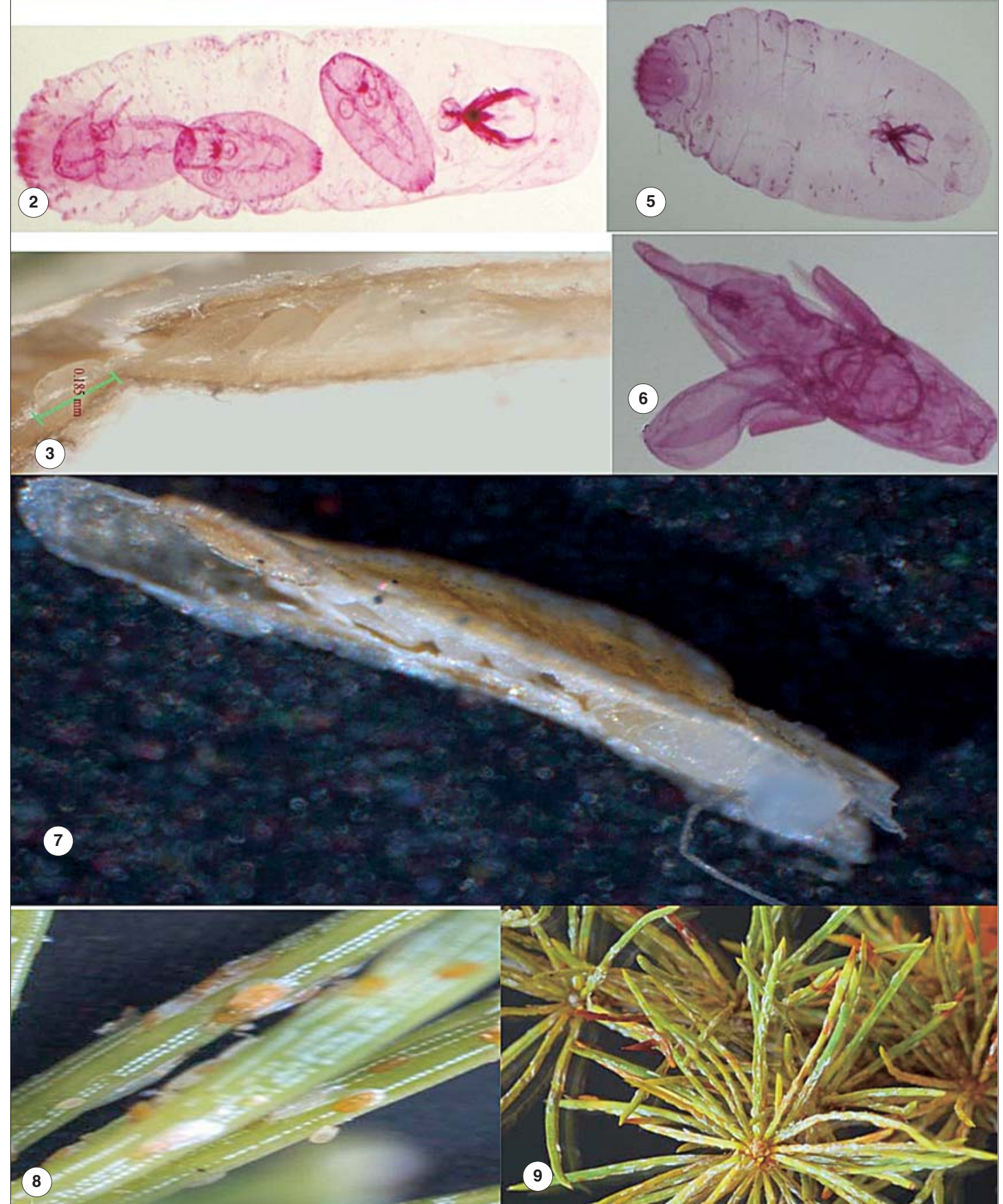

Fig. II - Eggs $(1,3)$ first instar $(2,4,6)$ and second instar nymphs $(5,8)$, pupa (6), ovoposited female (7), and damage pf Torosaspis cedricola (9).

week of September (7 weeks). Pupae and males occurred in cedar population between 6.viii.2008 and 2.x.2008 (Fig. III, IV). The free-living adult males are yellow and possess a single pair of clear wings, one pair of ocelli, and antennae with ten segments. The first adult females of this generation were found the first week of August (Fig. III, IV). After copulation, males die, and mated females are overwinter.
The overwintering period lasts more than 35 weeks and is the longest period in the life cycle of cedar scale (Fig. III, IV). Female remained in diapause up to climatic temperature in Ankara whereas the temperature is changed minus 9.819.4 $\mathrm{C}^{\circ}$ (November- March) in Ankara (Fig. V). They began to feed near the end of April, and their bodies grew slightly. In 2009, the first eggs were found at the end of May. 
Table 1 - Eggs number of Torosaspis cedricola (Balachowsky\&Alkan) on Cedrus libani in Ankara.

\begin{tabular}{|c|c|c|c|c|}
\hline \hline \multirow{2}{*}{ Localities } & \multicolumn{2}{|c|}{2008} & \multicolumn{2}{|c|}{2009} \\
\cline { 2 - 5 } & I. generation & II. generation & I. generation & II. generation \\
\cline { 2 - 5 } & & & & \\
\hline AF $^{1}$ & $4,22(1.68-5,30)$ & $2,61(1,69-3.50)$ & $4,39(1,72-5,52)$ & $3,41(1,66-5.08)$ \\
\hline Kurtuluş Park & $4,96(3,75-5,44)$ & $2,73(1,78-4,90)$ & $4,86(2,00-5,45)$ & $3,88(1.78-4.75)$ \\
\hline IFR $^{2}$ & $3,76(2,81-4,89)$ & $3,33(0,93-5,08)$ & $3,98(2,81-4,83)$ & $3,97(2,45-5,14)$ \\
\hline METU $^{3}$ & $4,37(2,56-5,18)$ & $3,78(0,57-5,04)$ & $4,38(2,54-5,18)$ & $4,04(1,25-5.02)$ \\
\hline
\end{tabular}

${ }^{1}$ Faculty of Agriculture, ${ }^{2}$ Institute of Forestry Research, ${ }^{3}$ Middle East Technical University.

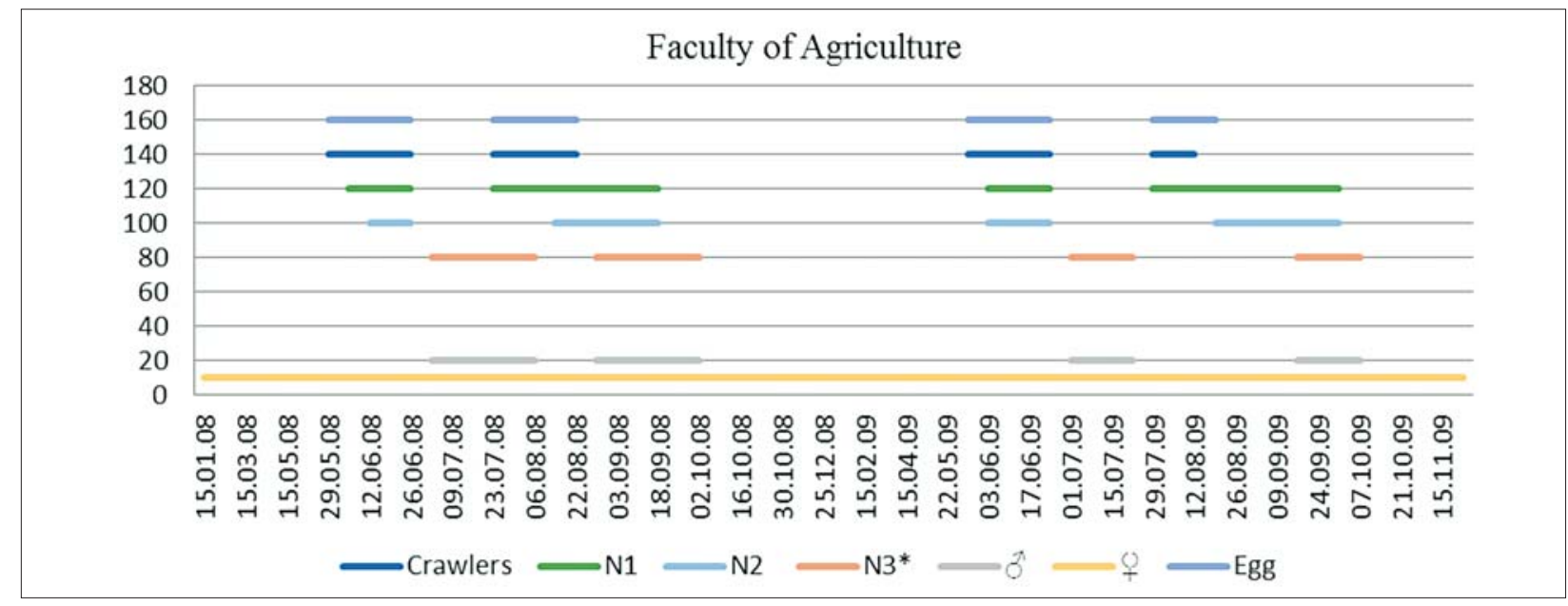

Fig. III - Duration of Torosaspis cedricola (Balachowsky\&Alkan) in Ankara (*Prepupa+pupae).

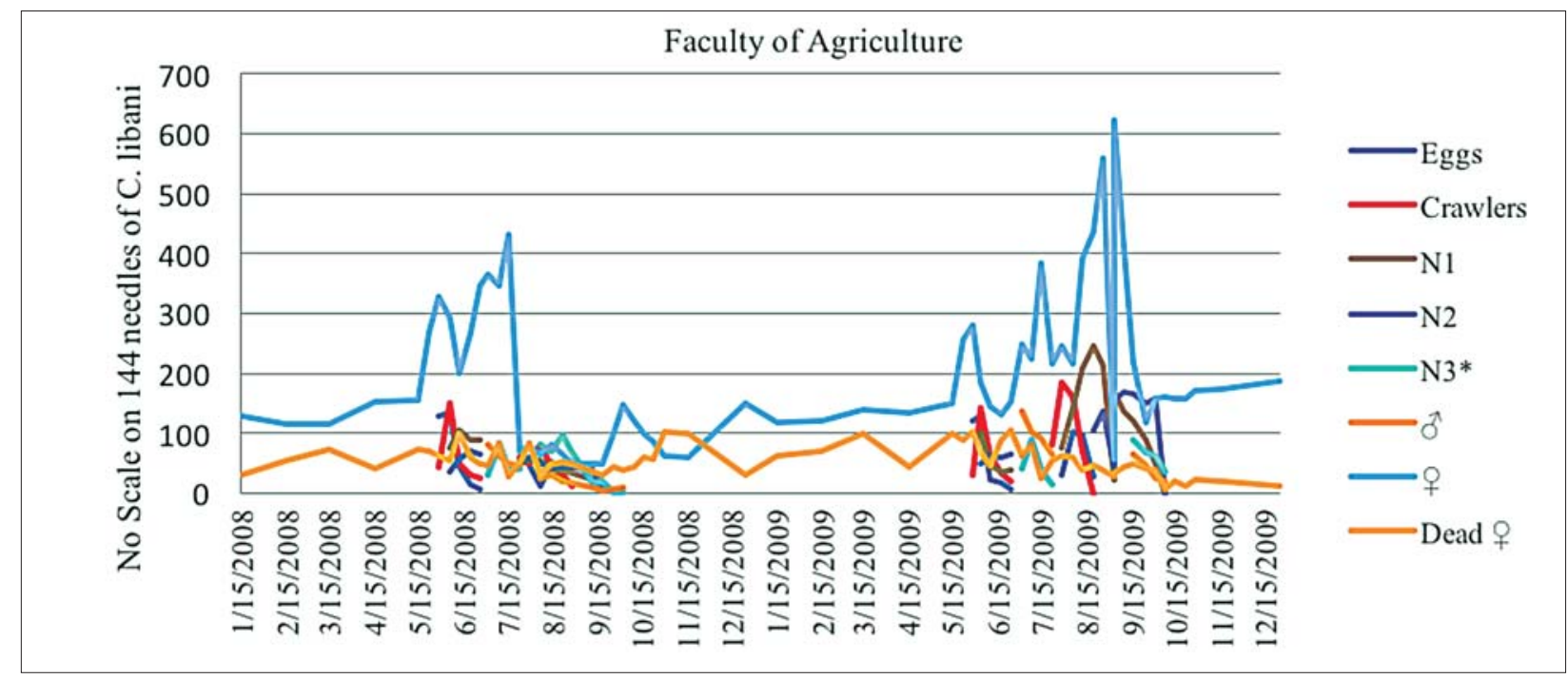

Fig. IV - Population fluctuation of Torosaspis cedricola (Balachowsky \& Alkan) in Ankara (*Prepupa+pupae).

Crawlers emergence and male flight occurred on nearly similar dates as the previously year. According to these results, T. cedricola has two generations per year in Ankara.

The population densities of $T$. cedricola female were significantly higher in 2009 than 2008 in all study areas (Table 2; Fig. III) but no significant differences between the sites within each year.

The sex ratio of $T$. cedricola ranged from 1.8:1-4.8:1

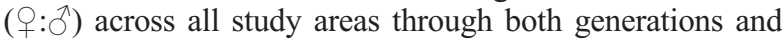

the sex ratio was strongly biased towards the female. In Agriculture Faculty, it was $64,59 \%$ female, $35,41 \%$ male for the first generation and $77,11 \%$ female, $22,89 \%$ male for the second generation (Table 3). An extremely female-biased sex ratio was reported by ALSTAD \& EDMUNDS (1983) in Dynaspidiotus (=Nuculaspis) californiaca (Coleman) growing on Pinus ponderosa. Additionally, RASEKH et al. (2011) reported that Dynaspidiotus abietis (Schrank) was female-biased in both second instar nymphs and adults. 


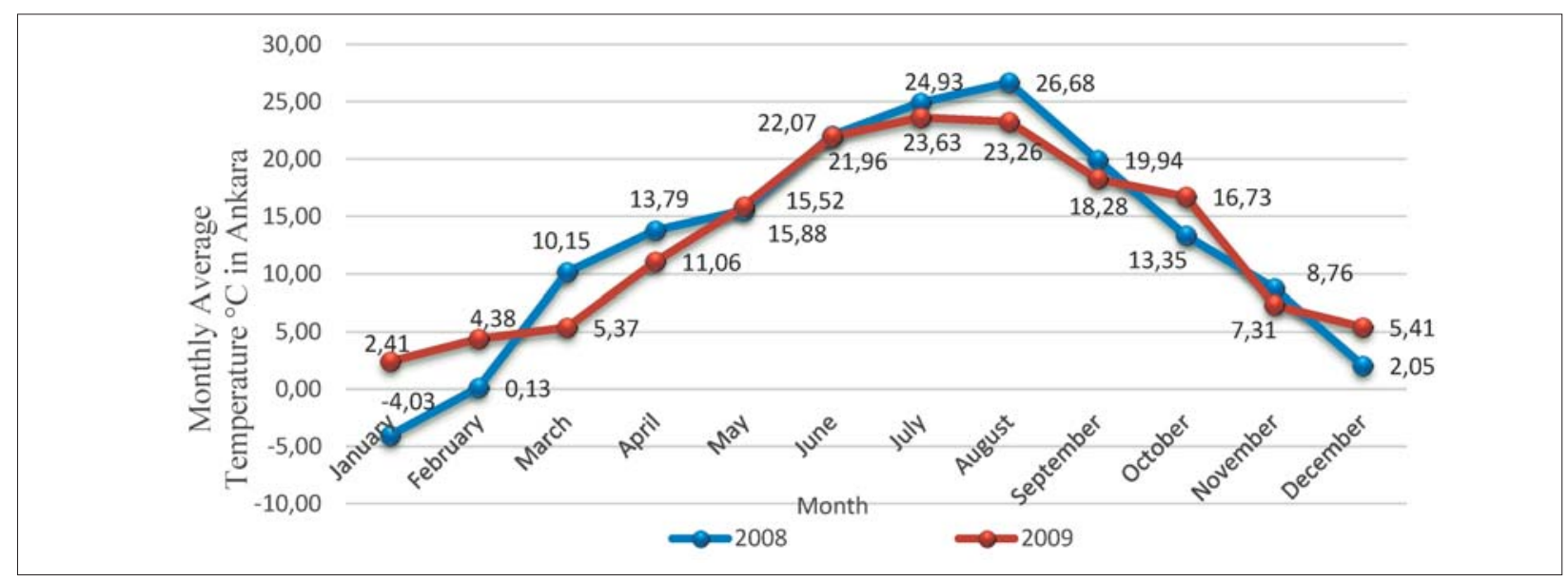

Fig. V - The monthly average temperature of Ankara in 2008-2009

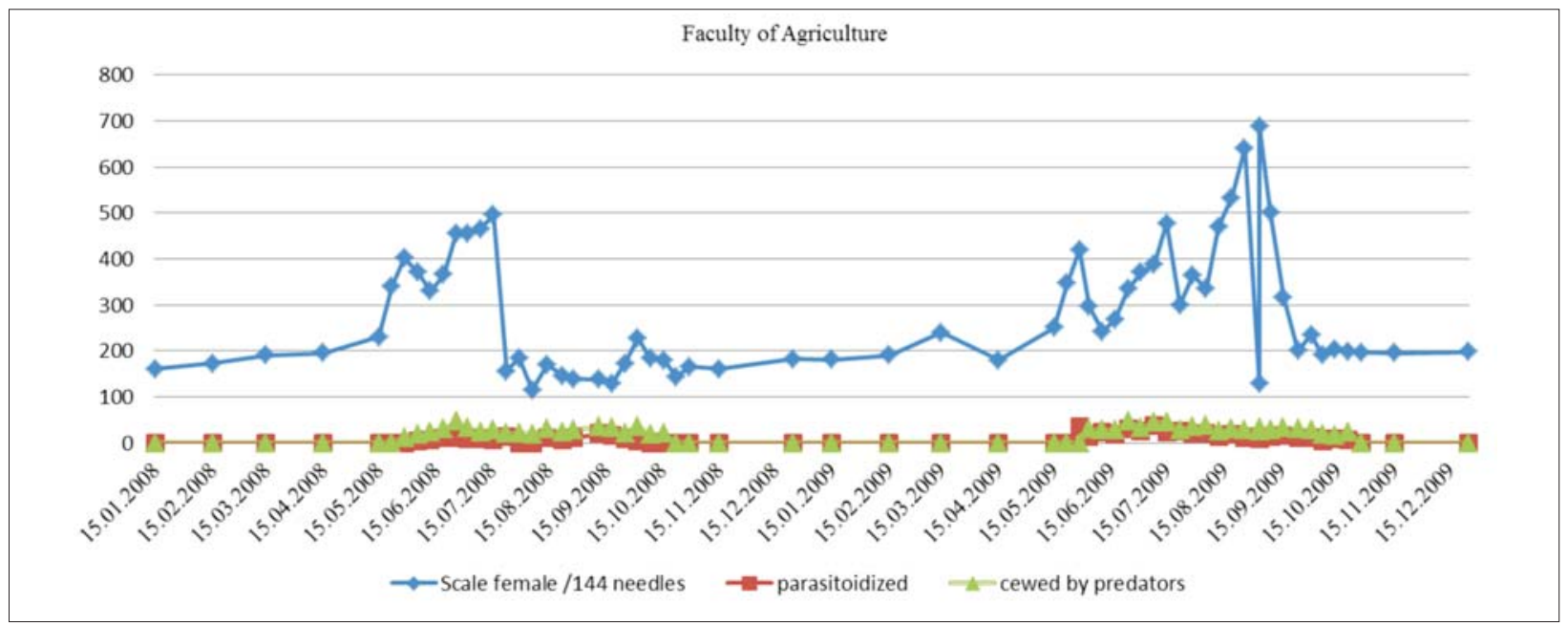

Fig. VI - Effects of natural enemies on Torosaspis cedricola (Balachowsky \& Alkan) population on Cedrus libani, in Ankara.

Table2 - Adult female number Torosaspis cedricola (Balachowsky\&Alkan) per needle of Cedrus libani in Ankara.

\begin{tabular}{|c|c|c|c|c|}
\hline Localities & $\mathrm{n}$ & 2008 & $\mathrm{n}$ & 2009 \\
\hline $\mathrm{AF}^{1}$ & 31 & $158,5 \pm 20,3(49-432) b$ & 31 & $234,8 \pm 23,4(118-622) \mathrm{a}$ \\
\hline Kurtuluş Park & 31 & $80,58 \pm 5,13(37-141) b$ & 31 & $218,4 \pm 17,8(108-458) a$ \\
\hline $\mathrm{IFR}^{2}$ & 31 & $92,55 \pm 6,93(45-180) b$ & 31 & $263 \pm 25,9(100-630) a$ \\
\hline METU $^{3}$ & 31 & $107,03 \pm 8(40-210) \mathrm{b}$ & 31 & $262,5 \pm 27,2(110-631) \mathrm{a}$ \\
\hline
\end{tabular}

${ }^{1}$ Faculty of Agriculture, ${ }^{2}$ Institute of Forestry Research, ${ }^{3}$ Middle East Technical University.

* In different rows and the difference between the mean values with different letters were significant $(\mathrm{P}<0.05)$.

NATURAL ENEMIES AND THEIR EFFECTS ON POPULATIONS OF CEDAR SCALE

Predators; Adalia bipunctata (L.), Chilocorus bipustulatus (L.), Brumus quadripustulatus (L.), Harmonia quadripunctata (Pont) and (Coleoptera: Coccinellidae) Cybocephalus fodori minör (Endrödy) (Coleoptera: Cybocephalidae) were associated with T. cedricola in Ankara (Table 2). A. bipunctata and H. quadripunctata were found in few numbers with Cedar scale. The reason for this is possibly that generalist and facultative predators. They feed on aphids and other small, soft bodied insects
(Uygun, 1980; ÜlgentürK \& Toros, 2001; ERLER et al., 2001; KAYDAN et al., 2006). Likewise, B. quadripustulatus was rarely found with cedar scale. Although $B$. quadripustulatus mainly feeds on mealybugs and soft scales, there records of it preying on diaspidids including $T$. cedricola (as A. cedricola) (UyGUN, 1980; DreA \& GORDOn, 1990; ÜLgENTÜRK. 2001). The coccinelids, $C$. bipustulatus and $C$. fodori minor were more common and occurred in higher numbers than the above predators with cedar scale. All predators fed upon T. cedricola during Maythe end of October both years. Predator activities increased 
Table 3 - The sex ratio of Torosaspis cedricola (Balachowsky\&Alkan) in Ankara.

\begin{tabular}{|c|c|c|c|c|c|c|}
\hline \multirow{2}{*}{ Localities } & \multicolumn{3}{|c|}{ I. generation } & \multicolumn{3}{|c|}{ II. generation } \\
\hline & q & $\hat{0}$ & $+:_{0}^{\lambda}$ & 우 & $\hat{\sigma}$ & $+: \hat{\sigma}$ \\
\hline $\mathrm{AF}^{1}$ & $\% 64,59$ & $\% 35,41$ & $1.8: 1$ & $\% 77,11$ & $\% 22,89$ & $3.3: 1$ \\
\hline Kurtuluş Park & $\% 68,16$ & $\% 31,84$ & $2.1: 1$ & $\% 65,46$ & $\% 34,54$ & $1.8: 1$ \\
\hline $\mathrm{IFR}^{2}$ & $\% 72,52$ & $\% 27,48$ & $2.6: 1$ & $\% 82,61$ & $\% 17,39$ & $4.8: 1$ \\
\hline METU $^{3}$ & $\% 76.01$ & $\% 23,99$ & $3.1: 1$ & $\% 75,420$ & $\% 24,58$ & $3: 1$ \\
\hline
\end{tabular}

in the middle of May and peaked in the middle of June. This corresponds to periods of oviposition and crawler emergence for cedar scale. Predation is slightly decreased during summer and autumn but continued until the end of October (Fig. VI). This possibly occurred for two reasons. Firstly, these predators are generalist, and they can immigrate to feed on other prey. Secondly, they could aestivate during hot, dry periods (DREA \& GORDON, 1990). Activities are reduced during the cold period, but they could feed under warmer condition. After winter period they are begun to feed with cedar scale in the middle of March slowly. Unfortunately, predators did not control effectively cedar scale in Ankara (Table 4, Fig. VI). C. bipustulatus was a predator of Aonidiella aurantii (Maskell), Chionaspis salicis L., Epidiasaspis leperii (Signoret), A. cedricola, Carulaspis juniper (Bouché), Diaspidiotus perniciosus Comstock, Dynaspidiotus (=Nuculaspis) abietis (Schrank), D. britanicus, Lepidosaphes ulmi Linnaeus, Leucaspis riccae (Targ.-Tozz.), Pseudaulacaspis pentagona Targ. Tozz., Salicicola africana (Newstead) and Unaspis euonymi (Comstock) (Hemiptera: Diaspididae) in Turkey (Schumutterer, 1953; Uygun, 1981; Kosztarab \& KOZÁR, 1988; ERLER \& TUNÇ, 2001, ÜLGENTÜRK \& TOROS, 2001; ÖZYURT \& ÜLGENTÜRK, 2007; AYHAN \& ÜLGENTÜRK, 2011; MOHAMMED et al., 2016).

C. fodori minör is a very small beetle and that preys on armored scale insects worldwide (DREA \& GORDON, 1990) T. cedricola, A. aurantii, Chrysomphalus dictyospermi (Morgan), Carulaspis minima (Signoret), D. europaea, D. perniciosus, E. leperii, L. ulmi, L. riccae, L. striata, Parlatoria oleae (Colveé), P. pentagona, and U. eunoymi were preyed upon $C$. fodori minör (ERKILIÇ \& UYGUN, 1995; ERLER \& TUNÇ, 2001, ÜLGENTÜRK \& TOROS, 2001)).
In Iran, C. fodori minör was consumed 20.81, 39.18 and $42.01 \%$ of Lepidosaphes pistaciae Arch. (Hemiptera: Diaspididae) settled on twigs, leaves and fruits of pistachio trees, respectively (KOLAHDOOZ et al., 2012).

The only parasitoid species emerging from cedar scale was Diaspiniphagus moeris (Walker) (Hymenoptera: Aphelinidae). Diaspiniphagus is considered a valid genus distinct from Coccophagoides and Coccophagoides moeris (Walker) was transferred to Diaspiniphagus Silvestri by HAYAT, (2011). Oval emergence holes of this parasitoid on cedar scale were first seen in the middle of May and continued until the second week of September. D. moeris hibernated inside female bodies as fully-fed larvae or pupae and adult wasps emerged the middle of May. Initial ratio of parasitism was relatively high but decreased at summer and autumn seasons (Fig 4). Parasitoids were ineffective in controlling T. cedricola populations. Possibly this was due to the high sulphur dioxide and dust levels on Cedar trees in Ankara (DostBIL, 2011). According to Viggiani (1990), female of D. moeris (=Coccophagoides. similis (Masi)) deposited fertilized eggs into young host female, rarely in second instar hosts and the larvae develop as primary parasites, whereas male development was period after hyperparasitic. In Turkey, D. moeris (as $C$. similis) attacked to $A$. aurantii in Antalya (ERLER \& TuNÇ, 2001), and before Torosaspis (as Acanthomytilus) cedricola, Diaspidiotus ostreaformis (Curtis) and Salicicola kermanensis (Lindinger) in Isparta provinces (JAPOSVILLI \& KARACA, 2002). In central Europe, this parasitoid (as C. similis) attacked to Chionaspis lepineyi Balachowsky, Diaspidiotus hungaricus Kosztarab, Diaspidiotus gigas (Thiem \& Gerneck), D. ostreaformis, D. abietis, E. leperii, Lepidosaphes conchiformis (Gmelin), L. ulmi, Leucaspis

Table 4 - Predators and parasitoid of Torosaspis cedricola (Balachowsky \& Alkan) on Cedrus libani, in Ankara.

\begin{tabular}{|c|c|}
\hline Species & Localities \\
\hline $\begin{array}{l}\text { Harmonia quadripunctata (Pont) } \\
\text { (Coleoptera: Coccinellidae) }\end{array}$ & Campus of Forestry Institute, $2+q ; 23 . v .2008$ \\
\hline $\begin{array}{l}\text { Adalia bipunctata }(\mathrm{L} .) \text { (Coleoptera: } \\
\text { Coccinellidae) }\end{array}$ & Campus of Agriculture $5 q q ; 2 \hat{\jmath}$, 23.v.2008; 11 adet 04.07.2008; \\
\hline $\begin{array}{l}\text { Chilocorus bipustulatus (L.) (Coleoptera: } \\
\text { Coccinellidae) }\end{array}$ & 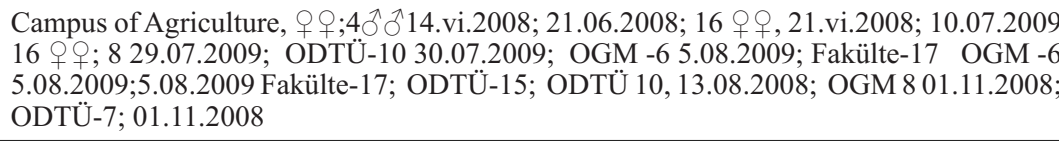 \\
\hline $\begin{array}{l}\text { Brumus quadripustulatus (L.) } \\
\text { (Coleoptera: Coccinellidae) }\end{array}$ & Faculty of Agriculture Campus, $7+q$, \\
\hline $\begin{array}{l}\text { Cybocephalus fodori minor (Endrödy) } \\
\text { (Coleoptera: Cybocephalidae) }\end{array}$ & $\begin{array}{l}\text { Faculty of Agriculture campus } 5 q q \text { 18.vi.2008; Kurtuluş Park } 5 q q, \quad 20 . v i .2008 \text {; } \\
\text { Institute of Forest Research campus } 5+q, 21 . v i .2008 ; 6++ \text {, 5.viii.2009; Middle East } \\
\text { Technical University, 21.vi.2008 }\end{array}$ \\
\hline $\begin{array}{l}\text { Diaspiniphagus moeris (Walker) } \\
\text { (Hymenoptera: Aphelinidae) }\end{array}$ & $\begin{array}{l}\text { ODTÜ, 04.07.2008; 10.07.2008; 22.07.2008; 10.08.2008; Cebeci, 15.vii.2009; Kurtuluş } \\
\text { Park, 15.vii.2009; ODTÜ 17.viii.2009; Cebeci, 1.ix.2009 }\end{array}$ \\
\hline
\end{tabular}


pusilla Löw, P. oleae, Targioni vitis (Signoret) and Unaspis euonymi (Comstock) (Hemiptera: Diaspididae) (KoszTARAB \& KOZAR, 1988)

In conclusion, even though Cedrus libani is high adaptability and high survival rate, high populations of $T$. cedricola have a very harmful effect on the trees, especially young cedar trees in parks and gardens in Ankara. High levels of Sulphur dioxide and dust limited the activities of natural enemies in urban planting of cedar. The very thin and small cedar scale is often difficult to detect on cedar needles, therefore it is many times too late to apply treatments for control once they are discovered. Treatments of insecticides should be directed at the crawler stages, at first in June and again if necessary, in August in parks and gardens in Ankara.

\section{ACKNOWLEDGEMENT}

The authors are grateful to Ankara University, Foundation of Scientific Research for supporting and identification of Aphelinidae and Coccinellidae species Prof. Dr Miktat Doğanlar and Prof. Dr Nedim Uygun respectively.

\section{REFERENCES}

Alstad D. N., Edmunds G. F. JR., 1983 - Adaptation, host specificity and gene flow in the black pine leaf scale. In: Variable Plants and Herbivores in Natural and Managed Systems. Denno R. F. \& McClure M. S., Eds. -Academic Press, New York. pp 413-426.

Ayhan B. Ülgentürk S., 2011 - Phenology of Dynaspidiotus britannicus (Newstead) (Hemiptera: Diaspididae) on the cedar in Ankara. In: Procedings of the $4^{\text {th }}$ Plant Protection Congress of Turkey, 2011 Kahramanmaraş, Turkey p.38

Balachowsky A.S., Alkan B., 1956 - Sur un Acanthomytilus Borkh. (Coccoidea-Diaspidini) nouveau vivant sur cèdre dans les montagnes de Turquie. (In French). - Bulletin et Annales de la Société Royale Entomologique de Belgique. Bruxelles 92: 319-323.

BILgen B.B., KurT Y. KaYA N., 2012 - Mating system in natural populations of Taurus cedar (Cedrus libani A.Rich.). - Turk J Agric For., 36: 379-387p.

BOYDAK M., 2003 - Regeneration of Lebanon cedar (Cedrus libani A.Rich.) on karstic lands in Turkey. Forest Ecology and Management. 178: 231-243.

BOYdAK M, ÇALIKOĞLU M., 2008 - Biology and Silviculture of Lebanon Cedar (Cedrus libani A. Rich.). OGEM-VAK, Ankara, p. 228 (in Turkish).

ÇANAKÇıIOĞLU, H. 1977 - Harmful Coccoidea (Hemiptera) species on forest trees and shrubs in Turkey. Istanbul University, Faculty of Forestry publications, İstanbul, No.: 2322, $122 \mathrm{pp}$.

Dagher-Kharrat M., Mariette S., Lefevre F., Fady B., March G.G., Plomion C., Savoure A., 2007 Geographical diversity and genetic relationships among Cedrus species estimated by AFLP. Tree Genetic Genomes 3: 275-285.

Drea J.J., Gordon, R.R., 1990 - Predators Coccinellidae, In:, Armored scale insects their biology, natural enemies, and control Vol. 4B., Rosen D. Ed., Elsevier, Amsterdam, the Netherlands pp. 19-40.

Dostbíl Ö., 2012 - Distribution and Bio-ecological studies on Cedar scale Torosaspis (Acanthomytilus) cedricola (Balachowsky \& Alkan) (Hemiptera:
Diaspididae) in Ankara. Ph D thesis Ankara University, $175 \mathrm{pp}$

ERLER F., TUNÇ I., 2001 - A survey (1992- 1996) of natural enemies of Diaspididae species in Antalya, Turkey. Phytoparasitica 29 (4) : 299-305.

ERKILIÇ L., UYGUN N., 1995 - Distribution, population fluctuations and natural enemies of the white peach scale, Pseudaulacaspis pentagona (Targioni tozetti) (Homoptera: Diaspididae) in the East Mediterranean Region of Turkey. - Israel Journal of Entomology, 33: 191-198.

EvCIMEN B.S., 1963 - The Economic Importance of Turkey Cedar Forests, Revenue and Forest Management Principles. General Directorate of Forestry Publication no: $355199 \mathrm{pp}$.

Hayat M., 2011 - On Coccophagoides Girault and Diaspiniphagus Silvestri (Hymenoptera: Chalcidoidea: Aphelinidae). - Zootaxa 3070: 15-22

JAPOSHVIli G., KARACA İ., 2002 - Coccid (Homoptera: Coccoidea) species of Isparta province, and their parasitoids from Turkey and Georgia. - Turk. J. Zool. 26: 371-376.

Kaydan M. B., Kilinçer N., Uygun N., Japosvilli G., Gaimari S., 2006 - Parasitoids and Predators of Pseudococcidae (Homoptera: Coccoidea) in Ankara, Turkey. - Phytoparasitica, 34 (4), 331-337.

Kaydan B., ÜlgentürK S., ÖZdemir I., Ulusoy M.R., 2014 - Coccoidea (Hemiptera) species in Bartın and Kastamonu Provinces. - Bulletin of Plant Protection, 54(1):11-44

Kolahdooz S. J., Basis M., Mahmudvand M., Seyed A. H., 2012 - Investigation into biological parameters and predatism trend of Cybocephalus fodori minör (Coleoptera: Cybocephalidae) on Lepidosaphes pistaciae (Homoptera: Diaspididae) in Isfahan province. - Plant Protection (Scientific Journal of Agriculture), 35 (1): 4353.

Kosztarab M., KozÁr F., 1988 - Scale insects of Central Europe. Akademiai Kiado, Budapest, Hungry. 456pp

Messinger J., GÜney A., Zimmermann R., Ganser B., Bachmann M., Remmele S. Aas G., 2015 - Cedrus libani: A promising tree species for Central European forestry facing climate change. - Eur. J. Forest. Res. 134: 1005.

Moghaddam M., 2004 - Insects of Iran. The list of Coccoidea in the Insect Museum of Hayk Mirzayans in Plant Pests and Diseases Research Institute. Publications, Plant Pests and Diseases Research Institute, Insect Taxonomy Research Department No.11: 55 pp.

Mohammed E. M. M. A., Ülgentürk S., Uygun N., Garonna A. P., Szentkiralayi F., Fent M., Hayat H., 2016 - The distribution, host plants and natural enemies of white peach scale, Pseudaulacaspis pentagona (Targioni-Tozzetti) (Hemiptera: Diaspididae), in Ankara Province. - Munis Entomology \& Zoology, 11 (2): 650656.

ÖZYURT Ö., ÜLGENTÜRK S., 2007 - Biology of Euonymus scale Unaspis euonymi (Hemiptera: Diaspididae) in Urban areas of Ankara Turkey. - Journal of Agricultural Sciences, 13(1): 47-53.

Qiao C.Y., Ran J.H., Li Y., Wang X.Q., 2007 - Phylogeny and biogeography of Cedrus (Pinaceae) inferred from sequences of seven paternal chloroplast and maternal mitochondrial DNA regions. - Ann. Bot. 100 (3): 573-580.

Rasekh A., Michaud J.P., VARANDil H. B., 2011 - Biology of the conifer needle scale, Nuculaspis abietis (Hemiptera: Diaspididae), in northern Iran and 
parasitism by Aspidiotiphagus citrinus (Hymenoptera: Aphelinidae). - Eur. J. Entomol. 108: 79-85,

SChumutTerer H., 1953 - Die ökologie der Cocciden (Hom.: Coccoidea) Frankens. 3.Abschnitt (schluss), 2. Abschitt. Zeitschr. F. Ang. Entomologie. Bd. 34, Heft: 1, 5-100. SELMI E., 1979 - The Research on harmful Coccoidea (Hemiptera) Species on Coniferous tree in the Marmara Region, - Istanbul University Faculty of Forestry Journal. Serial: A, Vol. 29 (1): 92- 127s.

SElmi E., 1979 - The Research on harmful Coccoidea (Hemiptera) Species on Coniferous tree in the Marmara Region. - Journal of Istanbul University Faculty of Forestry. Serial: A, Vol. 291 : 92- 127.

Senitza E., 1989 - Waldbauliche Grundlagen der Libanonzeder (Cedrus libani A. Rich.) im Westtaurus/Türkei. Dissertation der Universität für Bodenkultur in Wien, Wien 34 pp.

ŞAHIN Ö., ÜlgENTÜRK S., 2011 - Distribution of Torasaspis (Acanthomytilus) cedricola Balachowsky\& Alkan (Hemiptera: Diaspididae) in the Turkey. In: Turkey I. Forest Entomology and pathology Symposium, 2011, Antalya, Turkey . pp 261-265.

Ülgentürk S., Toros S., 1996 - Diaspididae species (Homoptera: Coccoidea) on park plants in Ankara. In: III. Congressof Entomology. Ankara University Faculty of Agriculture, Plant Protection Department, Ankara, Turkey, pp. 541-548

Ülgentürk S.,2001 - Parasitoids and Predators of
Coccidae (Homoptera: Coccoidea) Species on Ornamental Plants in Ankara, Turkey. - Acta Phytopathologica et Entomologica 36(3-4): 369-375

ÜlgentürK S., TOROs 2001 - Preliminary studies on parasitoids and predators of Diaspididae (Homoptera: Coccoidea) species on park plants. - Journal of Agri-cultural sciences, 6(4): 106-110.

ÜlgENTÜRK S., KoZÁR F., 2011 - A new scale insect genus, Torosaspis (Hemiptera: Sternorrhyncha: Coccoidea: Diaspididae), with a new species, Torosaspis turcica from Turkey Zootaxa 2907: 63-68.

Ülgentürk S., Şahin Ö., Ayhan B., SARIbaŞaK H. KAYDAN M, B., 2012 - Scale insect (Hemiptera: Coccoidea on the Taurus cedar (Cedrus libani) Turkey. Turkish journal of entomology, 36 (1): 113-121.

Ülgentürk S., Özdemir I., KozÁr F., Kaydan M.B., Dostbil Ö., SARIBAŞaK H., CiveleK H.S., 2013 Honeydew producing insect species in forest and neighboring areas in Western Turkey. - Bulletin of Turkish Entomology, 3 (4):125-135.

Uygun N., 1981 - Taxonomic research on Coccinellidae (Coleoptera) fauna of Turkey. Çukurova Univ., Faculty of Agriculture, Publ. No. 157. Adana, Turkey (Turkish, with English abstract)

VigGiani G., 1990 - Endoparasites. In: Armoured Scale Insects. Their Biology, Natural Enemies and Control. Vol. B. Rosen D. Ed., Elsevier, Amsterdam, the Netherlands. pp. 121-131. 